Article

\title{
Electrochemical Degradation of Phenol and Resorcinol Molecules through the Dissolution of Sacrificial Anodes of Macro-Corrosion Galvanic Cells
}

\author{
Boguslaw Pierozynski * and Grazyna Piotrowska \\ Department of Chemistry, Faculty of Environmental Management and Agriculture, \\ University of Warmia and Mazury in Olsztyn, Plac Lodzki 4, 10-727 Olsztyn, Poland; gp229@wp.pl \\ * Correspondence: bogpierozynski@yahoo.ca or boguslaw.pierozynski@uwm.edu.pl; Tel.: +48-89-523-4177; \\ Fax: +48-89-523-4801
}

Received: 30 April 2018; Accepted: 11 June 2018; Published: 12 June 2018

\begin{abstract}
This paper reports on the processes of phenol and resorcinol electrodegradation carried-out through continuous anodic dissolution of aluminum alloy and carbon steel sacrificial anodes for artificially aerated $\mathrm{Cu}-\mathrm{Al}$ alloy and $\mathrm{Cu}-\mathrm{Fe}$-based galvanic (macro-corrosion) cells and synthetically prepared wastewater solutions. Electrochemical experiments were carried-out by means of a laboratory size, PMMA (Poly-methyl methacrylate)-made electrolyser unit, where significant degrees of phenol (10-89\%) and resorcinol (13-37\%) decomposition were obtained and visualized through the respective chemical/spectroscopy analyses. In addition, quantitative determination of phenol, as well as resorcinol (and possible electrodegradation products) for the selected experimental conditions was performed by means of instrumental high-performance liquid chromatography/mass spectrometry analysis.
\end{abstract}

Keywords: phenol and resorcinol electrodegradation; galvanic cells; sacrificial anodes; HPLC/MS (high-performance liquid chromatography/mass spectrometry) analysis

\section{Introduction}

Phenolic compounds are widely generated side-products by a number of important industries, including: petrochemical, pharmaceutical and thermoplastic processing plants. Typical oil refinery wastewater could contain phenol in range of $500-1500 \mathrm{mg} \mathrm{dm}^{-3}$. Phenol and its derivatives (including resorcinol) are highly toxic environmental pollutants [1-6], which exhibit low biodegradability; they are also known as being severely toxic to human beings and aquatic life [7-10]. Electrochemical oxidation processes are very attractive methods for the degradation of phenolic compounds. Some previously published works on this topic covered oxidation of numerous phenolic compounds on a number of noble/semi-noble electrode materials (i.e., $\mathrm{Pt}, \mathrm{Ir}, \mathrm{Ru}$ ), as well as on transitional metals and their oxides $(\mathrm{Ti}, \mathrm{Sb}, \mathrm{Sn}, \mathrm{Pb}$ ), and various forms of carbon materials (glassy carbon, carbon fibre, graphite and boron-doped diamond electrodes), see Refs. [11,12], and articles quoted there for details. Some other important papers published on this topic explored the removal of phenol by means of the dc-driven electrocoagulation process, carried-out through anodic dissolution of $\mathrm{Al}$ and Fe electrodes [13-19]. The electrochemical coagulation method has significant benefits over a conventional, chemical coagulation process, as it allows for full process control through the adjustment of basic electrical (current and voltage) parameters. However, the necessity for application of very expensive, dc (or dc pulse) power supplies is its major disadvantage. Also, employment of anodes made practically of pure aluminum $[13,16,18,19]$ substantially increases electrical energy consumption, due to the effect of $\mathrm{Al}$ surface passivation. 
Therefore, this work is concerned with the removal of phenol and resorcinol molecules from synthetically-prepared wastewater solutions through the process of Al-alloy and Fe-mild steel self-electrocoagulation, realized in aerated, macro-corrosion galvanic cells (with no need for a dc power supply). Here, aluminum alloy and iron electrodes played the role of sacrificial anodes, whereas copper plates were employed as cathodes in order to make a galvanic cell operational $[20,21]$. Electrooxidation trials were performed for selected synthetic wastewater compositions. Monitoring of phenol/resorcinol decomposition processes (along with a quantitative evaluation of possible reaction products) was performed by means of commonly used, instrumental HPLC/MS analysis [22-24], in function of electrolysis time.

\section{Materials and Methods}

A PMMA (Poly-methyl methacrylate)-constructed wastewater electrolysis cell with ca. $750 \mathrm{~mL}$ of working volume was used in this work (see its schematic representation in Figure 1 below). The cell contained a single sacrificial anode in the centre [Al alloy (surface area: $\mathrm{S}_{\mathrm{Al}} \sim 38 \mathrm{~cm}^{2}$; cylinder; diameter: $\phi=4 \mathrm{~cm}$, thickness: $\mathrm{d}=1 \mathrm{~cm}$ ): 3.0-5.5 wt. $\% \mathrm{Zn}+0.016-0.040 \mathrm{wt} . \%$ In (MAKROMOR, Gdansk, Poland) or mild steel 1.0332 anode $\left(\mathrm{S}_{\mathrm{Fe}} \sim 56 \mathrm{~cm}^{2}\right.$; plate: $\left.\left.5 \times 5 \times 0.3 \mathrm{~cm}\right)\right]$ and two copper cathodes $\left(\mathrm{S}_{\mathrm{Cu}} \sim 84 \mathrm{~cm}^{2}\right.$; two plates: $4 \times 5 \times 0.1 \mathrm{~cm}$ ) located at two sides of the electrolyser, with an anode-to-cathode distance of about $20 \mathrm{~mm}$.

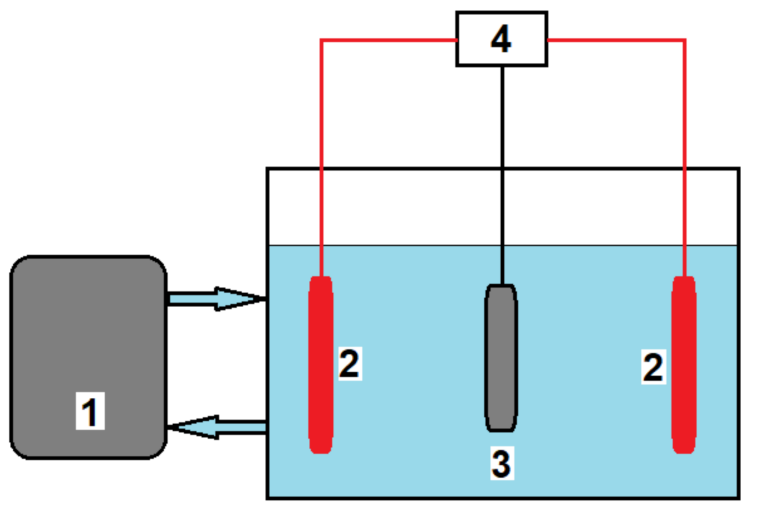

Figure 1. Schematic illustration of galvanic cell, wastewater electrolysis system, as follows: 1-Gilson Minipuls 3 peristaltic pump; 2-copper cathodes; 3-Al alloy or Fe sacrificial anode; 4-electrical connections.

Prior to being positioned in the cell, both sacrificial anodes were first polished with emery paper down to 2000 grade; then, they were activated for $5 \mathrm{~min}$ in $5 \% \mathrm{HCl}$ solution before being de-greased with acetone and rinsed with ultra-pure water $(18.2 \mathrm{M} \Omega \mathrm{cm}$ Millipore Q3 UV water purification system was used). On the other hand, $\mathrm{Cu}$ cathodes were activated in $5 \% \mathrm{HCl}$ and thoroughly rinsed with ultra-pure water. The electrolyser was operated at room temperature in a wastewater recirculation mode (at a rate of ca. $20 \mathrm{~mL} \mathrm{~min}^{-1}$ ), carried-out by means of Gilson Minipuls 3 peristaltic pump. Anodic dissolution of $\mathrm{Al}$ alloy (Fe electrode) was possible due to external connection of electrodes in order to make respective galvanic cells.

Open-circuit voltages and electrode potentials (recorded vs. SCE: saturated calomel electrode) were always measured prior to and after completion of the electrocoagulation tests. On the other hand, intermittent measurements of corrosion potentials (vs. SCE) and galvanic current readings for aerated (by slow purging of compressed air) cells were conducted every 60 min during the trials. Synthetic wastewater solutions were prepared by dissolving $\mathrm{Na}_{2} \mathrm{SO}_{4}$ (electrolyte conductivity: $\mathrm{K}=5.0$ and $10.0 \mathrm{mS} \mathrm{cm}^{-1}, \mathrm{pH}=7$ : re-adjusted and $\mathrm{HCl}$-adjusted acidic $\mathrm{pH}$ of 3 , and $\mathrm{t}=20^{\circ} \mathrm{C}$; Polish Chemical Compounds, p.a.) using Millipore ultra-pure water source with initial phenol [Ph] (Sigma-Aldrich, $>99 \%$, Poznan, Poland) and resorcinol [Res] (Polish Chemical Compounds, p.a.) concentrations on the 
order of $1 \times 10^{-4}$ and $1 \times 10^{-3} \mathrm{M}$. Although the selected concentrations of phenol and resorcinol are indeed quite high, one cannot exclude the possibility of limited phenol discharge to environment at the concentration of $1 \times 10^{-4} \mathrm{M}$ (or even higher) by a local company. On the other hand, the choice of $\mathrm{Na}_{2} \mathrm{SO}_{4}$ salt base (providing the necessary wastewater conductivity for galvanic cells' operation) in this work was primarily (in addition to simplicity) to avoid possible chlorination effects. Initial operation of $\mathrm{Cu} / \mathrm{Al}$ alloy and $\mathrm{Cu} / \mathrm{Fe}$ galvanic cells was also tested under analogous experimental conditions, but in the absence of phenol (resorcinol) in the electrolyte by means of the Solartron 12.608 W Full Electrochemical System (ZRA mode). Otherwise, all electrical measurements were conducted with Fluke $85 \mathrm{III}$ true rms multimeter, whereas $\mathrm{O}_{2}$ content, electrolyte conductivity and $\mathrm{pH}$ evaluations were carried-out with HI 9146, HI 9835, and HI 2002-01 meters from Hanna Instruments, respectively.

A major analysis of phenol content in wastewater was carried-out spectro-photometrically with 4-aminoantipyrine [25,26], where for every studied object two independent wastewater samples ( 5 and $10 \mathrm{~mL}$ ) were collected for initial solution and after 6 , and $12 \mathrm{~h}$ of the electrolyser's continuous operation. On the other hand, respective resorcinol analysis was carried-out based on the bromometric determination titration method $[27,28]$.

In addition, both phenol and resorcinol electrodegradation processes were subjected to a quantitative assessment of the reaction products/intermediates by means of the combined HPLC/MS analysis, carried-out for both galvanic cells $(\mathrm{Cu} / \mathrm{Al}$ alloy and $\mathrm{Cu} / \mathrm{Fe})$, at an initial concentration of $[\mathrm{Ph}]=1 \times 10^{-4} \mathrm{M}$ and $[\mathrm{Res}]=1 \times 10^{-3} \mathrm{M}$, and electrolyte conductivity of $5.2 \mathrm{mS} \mathrm{cm}^{-1}$, after 8 and $5 \mathrm{~h}$ of continuous electrolysis, correspondingly. Hence, the analyses were conducted by means of HPLC (LC 20 Prominence, Shimadzu, Japan) system combined with QTRAP 5500 mass spectrometer (AB SCIEX, Canada), equipped with an ESI ion source, triple quadrupole and an ionic trap. Reaction products were separated by means of XBridge C18 $(3.5 \mu \mathrm{m}, 150 \times 2.1 \mathrm{~mm})$ chromatographic column (Waters, Milford, MA, USA) at $45{ }^{\circ} \mathrm{C}$ for the mobile phase flow of $0.2 \mathrm{~mL} \mathrm{~min}^{-1}$. Both qualitative and quantitative analyses were conducted based on the MRM (Multiple Reaction Monitoring) method. The quantitative analysis was performed through the application of linear calibration curves $\left(R^{2}=0.993\right)$, based on a series of dilutions of external standards.

\section{Results and Discussion}

\subsection{Characterization of Macro-Corrosion, Galvanic Cells' Operation}

Initially, operation of $\mathrm{Cu} / \mathrm{Al}$ alloy (in comparison to $\mathrm{Cu} / \mathrm{Al}$ pure: 6063-T6 alloy) and $\mathrm{Cu} / \mathrm{Fe}$ galvanic cells was examined in aerated, $\mathrm{Na}_{2} \mathrm{SO}_{4}$-based electrolyte $\left(\mathrm{pH}=7, \mathrm{k}=5.0 \mathrm{mS} \mathrm{cm}^{-1}, \mathrm{t}=20^{\circ} \mathrm{C}\right.$ and ca. $10.5 \mathrm{ppm}$ of dissolved oxygen). Hence, after about half an hour, the $\mathrm{Cu} / \mathrm{Al}$ alloy, the $\mathrm{Cu} / \mathrm{Al}$ pure and the $\mathrm{Cu} / \mathrm{Fe}$ galvanic cells exhibited the following steady values of open circuit voltage: $1.034 \mathrm{~V}$, $0.537 \mathrm{~V}$ and $0.557 \mathrm{~V}$, correspondingly (Figure 2a).

Then, the corrosion behavior of the respective galvanic couplings is shown in Figure $2 b$. Hence, the galvanic couple built by shortening copper cathode with aluminum alloy anode exhibited the largest value of galvanic current $\left(I_{\mathrm{gc}}\right)$ of about $55 \mathrm{~mA}\left(1.46 \mathrm{~mA} \mathrm{~cm}^{-2}\right)$ after $1 \mathrm{~h}$ of exposure time. On the other hand, under analogous experimental conditions, about $28 \mathrm{~mA}\left(0.50 \mathrm{~mA} \mathrm{~cm}{ }^{-2}\right)$ and only $2.7 \mathrm{~mA}$ $\left(0.12 \mathrm{~mA} \mathrm{~cm}^{-2}\right)$ were recorded for the $\mathrm{Cu} / \mathrm{Fe}$ and the $\mathrm{Cu} / \mathrm{Al}$ pure galvanic couples, correspondingly. In all cases, an anodic process corresponds to dissolution of the so-called sacrificial anode ( $\mathrm{Al}$ or $\mathrm{Fe}$ electrode, see Equations (1)-(4) and Figure 2c below), whereas radically inhibited oxidation of pure aluminum anode results from the fact that $\mathrm{Al}$ (unlike some of its alloys) is highly-susceptible to the surface formation of thick, electrically insulating and exceptionally corrosion resistant oxide layer.

Hence, cations of the so-called "coagulating agent" (Al or Fe) are released in anodic oxidation process (Equation (1)), which is accompanied by cathodic hydrogen evolution or predominantly by oxygen reduction reaction on the copper electrode surface (Equation (2)), leading to a gradual increase of the solution's $\mathrm{pH}$ value. The latter finally results in the formation of aluminum or iron hydroxide (eventually Fe oxide) species, which is shown in Equations (3) and (4) above. Also, prolonged exposure 
of the galvanic cells under experimental conditions results in a radical modification of the sacrificial anode's surface structure (Figure 2c).

$$
\begin{aligned}
& \text { Anode: } \mathrm{Al}(\mathrm{s}) \rightarrow \mathrm{Al}^{3+}+3 \mathrm{e}^{-} \\
& \mathrm{Fe}(\mathrm{s}) \rightarrow \mathrm{Fe}^{2+}+2 \mathrm{e}^{-} \\
& \text {Cathode: } 2 \mathrm{H}_{2} \mathrm{O}+2 \mathrm{e}^{-} \rightarrow \mathrm{H}_{2} \uparrow+2 \mathrm{OH}^{-} \\
& \mathrm{O}_{2}+2 \mathrm{H}_{2} \mathrm{O}+4 \mathrm{e}^{-} \rightarrow 4 \mathrm{OH}^{-} \\
& 2 \mathrm{Fe}^{2+}+4 \mathrm{OH}^{-} \rightarrow 2 \mathrm{Fe}(\mathrm{OH})_{2}(\mathrm{~s})+\frac{1}{2} \mathrm{O}_{2} \rightarrow \mathrm{Fe}_{2} \mathrm{O}_{3}(\mathrm{~s})+2 \mathrm{H}_{2} \mathrm{O} \\
& \mathrm{Al}^{3+}+3 \mathrm{OH}^{-} \rightarrow \mathrm{Al}(\mathrm{OH})_{3}(\mathrm{~s})
\end{aligned}
$$
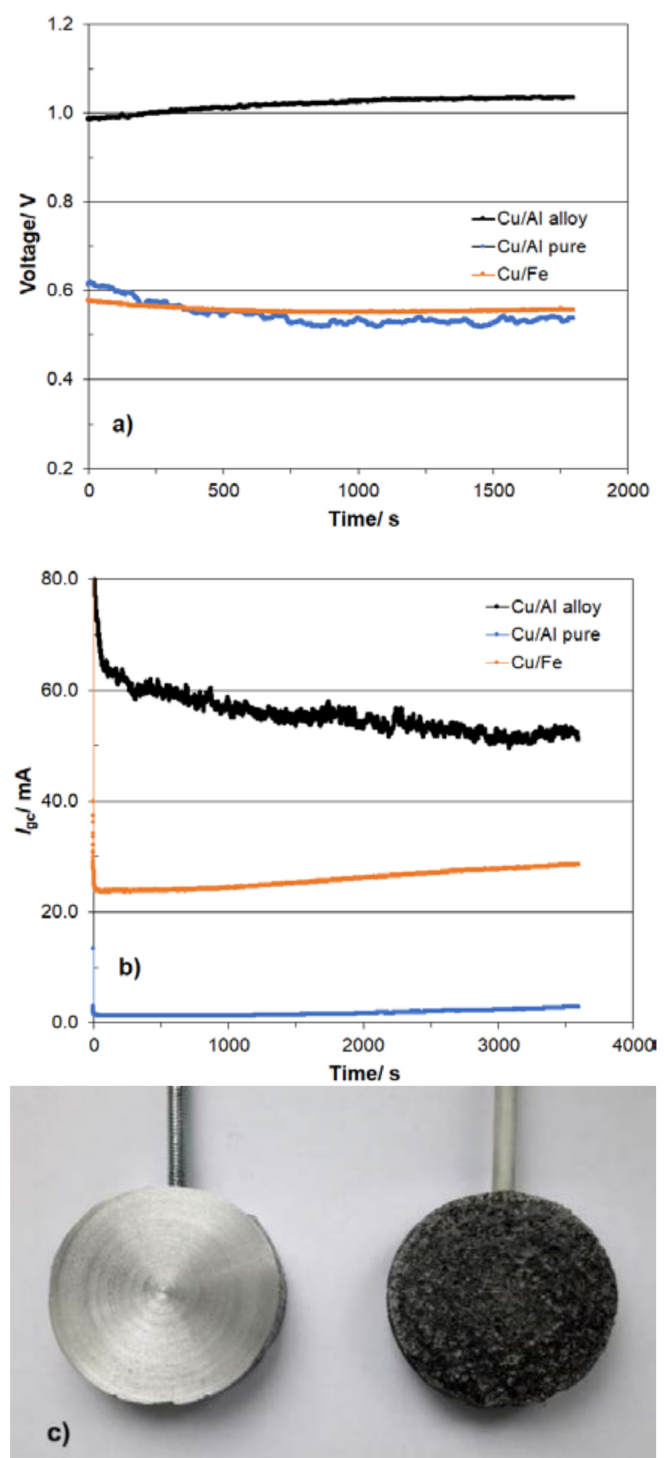

Figure 2. (a) Recorded values of open circuit voltage for $\mathrm{Cu} / \mathrm{Al}$ alloy, $\mathrm{Cu} / \mathrm{Al}$ pure and $\mathrm{Cu} / \mathrm{Fe}$ galvanic cells, derived for freshly-prepared, aerated $\mathrm{Na}_{2} \mathrm{SO}_{4}$ solution $\left(\mathrm{pH}=7, \mathrm{k}=5.0 \mathrm{mS} \mathrm{cm}{ }^{-1}, \mathrm{t}=20{ }^{\circ} \mathrm{C}\right.$ and 10.5 ppm of dissolved $\mathrm{O}_{2}$ ). (b) Recorded galvanic couple currents for stated cells in function of exposure time (other details as in Figure 2a above). (c) Visual condition of sacrificial Al alloy electrode prior to (left) and after (right) the long-time exposure as a galvanic couple with copper cathode. 


\subsection{Electrodegradation of Phenol and Resorcinol Molecules}

Figure 3a presents comparative efficiency of phenol removal obtained on aluminum alloy and mild steel sacrificial anodes, respectively. Hence, under a baseline set of working parameters $\left([\mathrm{Ph}]=1 \times 10^{-4} \mathrm{M}, \mathrm{\kappa}=5.0 \mathrm{mS} \mathrm{cm}^{-1}\right.$ and $\left.\mathrm{pH}=7\right)$, the copper/aluminum alloy and copper/iron galvanic cells allowed for the removal of $33 \%$ and $41 \%$ of phenol after $12 \mathrm{~h}$ of continuous operation of the electrolysis cell. Then, for a radically increased electrolyte conductivity $\left(\kappa=10.0 \mathrm{mS} \mathrm{cm}^{-1}\right)$ and under acidic $\mathrm{pH}$ of 3 , the efficiency of phenol removal was raised to $53 \%$ and $89 \%$ for the $\mathrm{Cu} / \mathrm{Al}$ alloy and the $\mathrm{Cu} / \mathrm{Fe}$ system, respectively.

Finally, for a 10-fold increase in initial concentration of phenol $\left(1 \times 10^{-3} \mathrm{M}\right)$, its removal efficiency significantly dropped to reach only about $10 \%$ and $21 \%$ for these cells, correspondingly. As high concentrations of phenol in the electrolyzed wastewater are strongly detrimental to the efficiency of its electrooxidation, it is also worth noticing in Figure 3 a that the process is quite vigorous only during initial hours of its operation. The above could most likely be related to surface electrosorptive nature of phenol molecule and its oxidation intermediates.
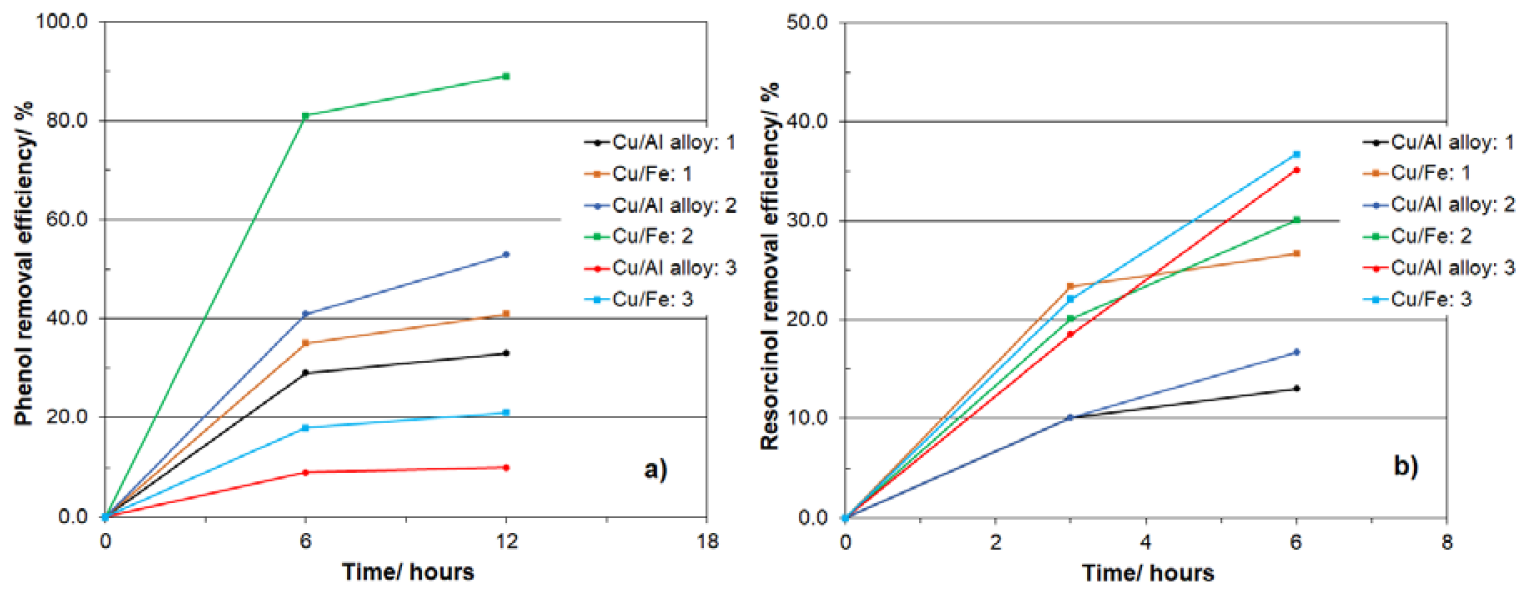

Figure 3. (a) Efficiency of phenol removal from synthetically $\left(\mathrm{Na}_{2} \mathrm{SO}_{4}\right)$-prepared wastewater through the employment of $\mathrm{Cu} / \mathrm{Al}$ alloy and $\mathrm{Cu} / \mathrm{Fe}$ galvanic couples, for the following conditions: 1- $[\mathrm{Ph}]=1 \times 10^{-4} \mathrm{M}, \mathrm{k}=5.0 \mathrm{mS} \mathrm{cm}^{-1}, \mathrm{pH}=7 ; 2-[\mathrm{Ph}]=1 \times 10^{-4} \mathrm{M}, \mathrm{k}=10.0 \mathrm{mS} \mathrm{cm}^{-1}, \mathrm{pH}=3$; $3-[\mathrm{Ph}]=1 \times 10^{-3} \mathrm{M}, \mathrm{K}=5.0 \mathrm{mS} \mathrm{cm}^{-1}, \mathrm{pH}=7$; (b) As in (a) above, but for resorcinol and the following conditions: 1 - $\left[\right.$ Res] $=1 \times 10^{-4} \mathrm{M}, \mathrm{k}=5.0 \mathrm{mS} \mathrm{cm}^{-1}, \mathrm{pH}=7 ; 2-[\operatorname{Res}]=1 \times 10^{-4} \mathrm{M}, \mathrm{k}=10.0 \mathrm{mS} \mathrm{cm}^{-1}$, $\mathrm{pH}=7 ; 3-[\operatorname{Res}]=1 \times 10^{-3} \mathrm{M}, \mathrm{k}=5.0 \mathrm{mS} \mathrm{cm}^{-1}, \mathrm{pH}=7$.

It should also be stressed here that the results obtained in this work are generally in good agreement with those recorded by other authors in Refs. [13-16] on the removal of phenolic compounds through the employment of direct current-driven dissolution of $\mathrm{Al}$ (or Fe) electrodes, i.e., the so-called electrocoagulation processes. As in this work the process of phenol removal was significantly facilitated with iron electrocoagulant, it could then be assumed that in contrast to Al electrode, Fe provides considerably greater surface area for the resulting flocs.

On the other hand, Figure $3 b$ illustrates comparative efficiency of resorcinol removal from synthetically-prepared wastewater, again for aluminum alloy and mild steel anodes. Thus, for the base conditions ([Res] $=1 \times 10^{-4} \mathrm{M}, \mathrm{k}=5.0 \mathrm{mS} \mathrm{cm}^{-1}$ and $\mathrm{pH}=7$ ), the copper/aluminum alloy and copper/iron galvanic cells exhibited the resorcinol removal levels on the order of $13 \%$ and $27 \%$ just after $6 \mathrm{~h}$ of continuous electrolysis. Then, under a double value of the electrolyte conductivity, the efficiency of resorcinol removal somewhat increased to reach $17 \%$ and $30 \%$ for the $\mathrm{Cu} / \mathrm{Al}$ alloy and the $\mathrm{Cu} / \mathrm{Fe}$ cell, correspondingly. Interestingly, for a 10-fold increase of initial concentration of resorcinol $\left(1 \times 10^{-3} \mathrm{M}\right)$, contrary to what was observed for phenol, the removal efficiency of resorcinol significantly increased, reaching very similar values for both examined systems, namely: 35\% and 37\% for the $\mathrm{Cu} / \mathrm{Al}$ alloy and 
the $\mathrm{Cu} / \mathrm{Fe}$ cells, respectively. The latter effect might be related to the fact that due to the presence of two hydroxyl groups in the meta position, the process of resorcinol electrodegradation could proceed considerably faster than that of phenol under analogous experimental conditions (e.g., see Ref. [29] for details).

Finally, Table 1 presents ranges of open-circuit voltage $\left(V_{\mathrm{oc}}\right)$ and electrode (cathode and anode) potential $\left(E^{0}\right)$ along with corrosion potential $\left(E_{\mathrm{cor}}\right)$ and galvanic current-intensity $\left(I_{\mathrm{gc}}\right)$ values for shorted cells, recorded during phenol and resorcinol electrodegradation experiments. Hence, the $\mathrm{Cu} / \mathrm{Al}$ alloy galvanic cell exhibited $V_{\mathrm{oc}}$ values on the order of 1.057-1.195 V, while open-circuit voltages of the $\mathrm{Cu} / \mathrm{Fe}$ cell were limited to the range $0.612-0.650 \mathrm{~V}$, which is governed by (comparatively to Fe) very anodic potential of the aluminum sacrificial anode (shown in Table 1 vs. SCE). As a result, the $\mathrm{Cu} / \mathrm{Al}$ alloy couple exhibited considerably larger values of galvanic current (42-56 mA), as compared to 18-28 mA demonstrated by the $\mathrm{Cu} / \mathrm{Fe}$ galvanic couple. In fact, rather qualitative nature of the recorded galvanic current parameter did not allow for the derivation of any electrical energy or electrode consumption values. In addition, estimated corrosion (mixed) potentials for both galvanic couples oscillated around the recorded open-circuit anode potentials (Table 1), which proved that corrosion processes proceeded with cathodic control governed by the kinetics of cathodic oxygen reduction or hydrogen evolution reactions (Equation (2)).

Table 1. Recorded ranges of electrical parameters (open-circuit voltage and electrode potential, mixed-corrosion potential and galvanic current-intensity) for $\mathrm{Cu} / \mathrm{Al}$ alloy and $\mathrm{Cu} / \mathrm{Fe}$ galvanic couples, obtained upon phenol and resorcinol electrodegradation experiments.

\begin{tabular}{|c|c|c|c|c|}
\hline \multicolumn{5}{|c|}{$\mathrm{Cu} / \mathrm{Al}$ Alloy Galvanic Cell } \\
\hline $\begin{array}{c}\boldsymbol{V}_{\mathbf{~ o c}} / \mathbf{V} \\
1.057-1.195\end{array}$ & $\begin{array}{c}\boldsymbol{E}^{\mathbf{0}} \mathbf{A l}_{\mathbf{S C}}(\mathrm{SCE}) / \mathbf{V} \\
-1.191-(-1.207)\end{array}$ & $\begin{array}{c}E^{0}{ }_{\mathrm{Cu}}(\mathrm{SCE}) / \mathbf{V} \\
-0.029-(-0.060)\end{array}$ & $\begin{array}{c}E_{\text {cor }}(\mathbf{S C E}) / \mathbf{V} \\
-0.918-(-1.024)\end{array}$ & $\begin{array}{c}I_{\mathrm{gc}} / \mathbf{m A} \\
42-56\end{array}$ \\
\hline \multicolumn{5}{|c|}{$\mathrm{Cu} / \mathrm{Fe}$ Galvanic Cell } \\
\hline $\begin{array}{c}\boldsymbol{V}_{\mathbf{~ o c}} / \mathbf{V} \\
0.612-0.650\end{array}$ & $\begin{array}{c}E^{0} \mathbf{F e}(\mathrm{SCE}) / \mathrm{V} \\
-0.605-(-0.705)\end{array}$ & $\begin{array}{c}E^{0} \mathrm{Cu}(\mathrm{SCE}) / \mathbf{V} \\
-0.017-(-0.092)\end{array}$ & $\begin{array}{c}E_{\text {cor }}(\mathbf{S C E}) / \mathbf{V} \\
-0.514-(-0.615)\end{array}$ & $\begin{array}{c}I_{\mathrm{gc}} / \mathrm{mA} \\
18-28\end{array}$ \\
\hline
\end{tabular}

\subsection{Phenol and Resorcinol Electrodegradation by HPLC/MS (High Performance Liquid Chromatography/Mass} Spectrometry) Analysis

Furthermore, the combined HPLC/MS analysis (important with respect to derivation of the mechanisms for phenol and resorcinol electrodegradation, based on instrumental identification of the reactions by-products) was carried-out on four freshly (within $24 \mathrm{~h}$ ) pre-electrolyzed wastewater samples (having removed all Fe III and Al hydroxide precipitates), for the following parameters:

Sample 1: $[\mathrm{Ph}]=1 \times 10^{-4} \mathrm{M} \& \mathrm{Cu} / \mathrm{Al}$ alloy; $\mathrm{k}=5.2 \mathrm{mS} \mathrm{cm}^{-1}, \mathrm{pH}=7, I_{\mathrm{gc}}=30 \mathrm{~mA}, \mathrm{t}=8 \mathrm{~h}$

Sample 2: $[\mathrm{Ph}]=1 \times 10^{-4} \mathrm{M} \& \mathrm{Cu} / \mathrm{Fe} ; \mathrm{k}=5.2 \mathrm{mS} \mathrm{cm}^{-1}, \mathrm{pH}=7, I_{\mathrm{gc}}=15 \mathrm{~mA}, \mathrm{t}=8 \mathrm{~h}$

Sample 3: $[$ Res $]=1 \times 10^{-3} \mathrm{M} \& \mathrm{Cu} / \mathrm{Al}$ alloy; $\mathrm{k}=5.2 \mathrm{mS} \mathrm{cm}^{-1}, \mathrm{pH}=7, I_{\mathrm{gc}}=50 \mathrm{~mA}, \mathrm{t}=5 \mathrm{~h}$

Sample 4: $[$ Res $]=1 \times 10^{-3} \mathrm{M} \& \mathrm{Cu} / \mathrm{Fe} ; \mathrm{k}=5.2 \mathrm{mS} \mathrm{cm}^{-1}, \mathrm{pH}=7, I_{\mathrm{gc}}=25 \mathrm{~mA}, \mathrm{t}=5 \mathrm{~h}$.

It should be noted however that the electrodegradation conditions to get the samples for HPLC/MS analysis were not much different from those of Figure 3. Thus, phenol analysis (Samples 1 and 2) resembles that of baseline conditions in Figure 3a (data series: 1). On the other hand, resorcinol analysis (Samples $\mathbf{3}$ and $\mathbf{4}$ ) is similar to that of data series $\mathbf{3}$ in Figure 3b. Also, a time variation should not be significantly (except for a typical fluctuation) affecting electrolyte's final composition, as: (a) for phenol electrodegradation: 8-h electrolysis time fits plateaus observed in Figure 3a, and (b) for resorcinol electrodegradation: 5-h electrolysis time is close to the maximum recorded analysis time in Figure 3b.

Thus, both phenol, as well as resorcinol electrooxidation on the $\mathrm{Al}$ alloy (or Fe) electrode surface (for sulphate-based synthetic wastewater) resulted in lack of ring-based degradation intermediates 
(see Figure $4 \mathrm{a}, \mathrm{b}$, and Table 2 below). In fact, the only quantitatively identified product for these processes was maleic acid, estimated at $8.0 \times 10^{-7} \mathrm{M}$ for electrodegradation of resorcinol on the surface of iron electrode (Sample 4). Moreover, instrumentally derived (Table 2) concentrations of phenol (Samples 1 and 2) and resorcinol (Samples 3 and 4) could be translated to about 18\%, 33\%, 11\% and $44 \%$ of removed phenol (resorcinol), correspondingly. These numbers are in qualitative agreement with those recorded above by the bromometric titration method.

Hence, the most important information obtained from the HPLC/MS instrumental analysis is that both phenol and resorcinol electrooxidation processes, performed through the dissolution of sacrificial $\mathrm{Al}$ alloy (or $\mathrm{Fe}$ ) anode material, proceeded with a total destruction of the aromatic ring structure, where maleic and oxalic acids, and $\mathrm{CO}_{2}$ are supposedly their key reaction products (see a tentative degradation pathway for phenol and resorcinol molecules in Figure 5 below).

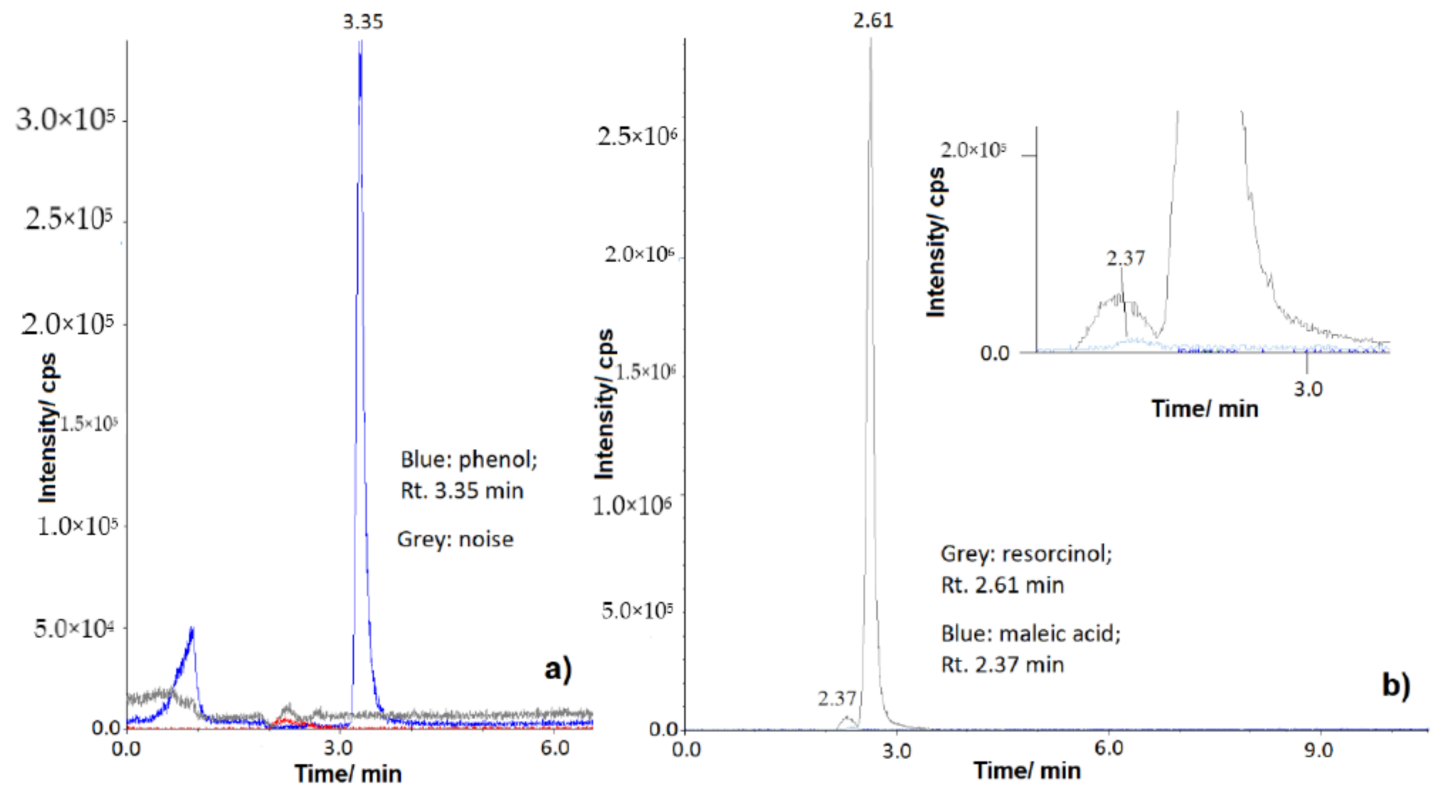

Figure 4. (a) HPLC chromatograms recorded for phenol-based, electrolyzed synthetic wastewater solution (Sample 1); (b) As in (a) above, but for resorcinol, exhibiting (scarcely visible) detected maleic acid as an intermediate product of resorcinol electrodegradation (Sample 4).

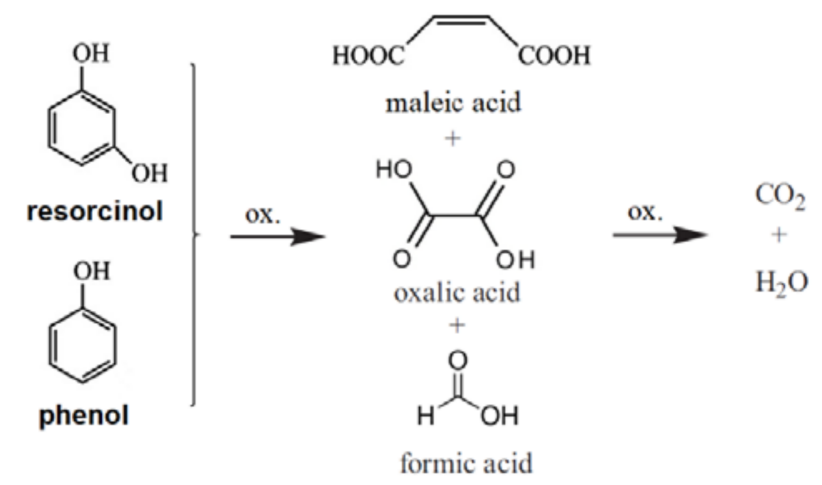

Figure 5. A tentative pathway for phenol and resorcinol electrodegradation. 
Table 2. Quantitative determination of phenol and resorcinol, and their possible electrodegradation products, obtained from phenol (resorcinol)-based, pre-electrolyzed synthetic wastewater solution, identified by means of HPLC/MS instrumental analysis.

\begin{tabular}{cccc}
\hline & \multicolumn{3}{c}{ Phenol Electrooxidation/M } \\
\hline Sample & Galvanic cell & Phenol & - \\
\hline $\mathbf{1}$ & $\mathrm{Cu} / \mathrm{Al}$ alloy & $8.2 \times 10^{-5}$ & \\
$\mathbf{2}$ & $\mathrm{Cu} / \mathrm{Fe}$ & $6.7 \times 10^{-5}$ & \\
\hline & & Resorcinol Electrooxidation/M & \\
\hline Sample & Galvanic cell & Resorcinol & Maleic acid \\
\hline $\mathbf{3}$ & $\mathrm{Cu} / \mathrm{Al}$ alloy & $8.9 \times 10^{-4}$ & - \\
$\mathbf{4}$ & $\mathrm{Cu} / \mathrm{Fe}$ & $5.6 \times 10^{-4}$ & $8.0 \times 10^{-7}$ \\
\hline
\end{tabular}

\section{Conclusions}

Processes of phenol and resorcinol electrodegradation could successfully be performed through electrocoagulation with $\mathrm{Al}$ and $\mathrm{Fe}$ ions, produced from sacrificial anodes for aerated, $\mathrm{Cu} / \mathrm{Al}$ alloy and $\mathrm{Cu} / \mathrm{Fe}$ galvanic couples. A key advantage of this process over a typical dc-driven $\mathrm{Al} / \mathrm{Fe}$ electrocoagulation is that its operation is purely based on the theory of a galvanic (corrosion) cell, where dissolution rate of anode is controlled by open-circuit potential difference between the cell's constituents, as well as the presence of a depolarizing agent (typically dissolved oxygen). Here, there is no necessity for expensive, dc rectifier infrastructure and control system. Aluminum alloy sacrificial anode is not susceptible to surface oxidation (passivation) phenomenon, which makes it superior in this application to pure aluminum. Furthermore, an advantage of iron electrode over aluminum is most likely related to considerably greater surface area of the resulting flocs for the former one.

Finally, performed HPLC/MS instrumental analysis implied that both phenol and resorcinol electrooxidation continued with total destruction of the aromatic ring structure, where maleic and oxalic acids, and carbon dioxide species would be the main reaction products. As laboratory size experiments proved general suitability of this electrochemical setup for the degradation of selected phenolic compounds, further work (including optimization of major process parameters: $\mathrm{pH}$, operating time and temperature) should be carried-out on a much bigger, technical scale system, which would allow for the purification of at least $1 \mathrm{~m}^{3}$ of wastewater per $24 \mathrm{~h}$ of continuous operation.

\section{Patents}

Pierozynski, B.; Smoczynski, L. Electrocoagulator for wastewater treatment, Patent of the Republic of Poland, PAT.227874, granted on 5 September 2017.

Author Contributions: B.P. designed, oversaw operation of the experiments and prepared final version of the manuscript; G.P. carried-out laboratory experiments and completed all data analyses.

Acknowledgments: This work has been financed by the internal research grant no. 20.610.001-300, provided by The University of Warmia and Mazury in Olsztyn. This research received no external funding.

Conflicts of Interest: The authors declare no conflict of interest.

\section{References}

1. Rajkumar, D.; Palanivelu, K. Electrochemical treatment of industrial wastewater. J. Hazard. Mater. 2004, B113, 123-129. [CrossRef] [PubMed]

2. Lv, G.; Wu, D.; Fu, R. Performance of carbon aerogels particle electrodes for the aqueous phase electro-catalytic oxidation of simulated phenol wastewaters. J. Hazard. Mater. 2009, 165, 961-966. [CrossRef] [PubMed]

3. Yang, X.; Kirsch, J.; Fergus, J.; Simonian, A. Modeling analysis of electrode fouling during electrolysis of phenolic compounds. Electrochim. Acta 2013, 94, 259-268. [CrossRef] 
4. Li, X.; Cui, Y.; Feng, Y.; Xie, Z.; Gu, J. Reaction pathways and mechanisms of the electrochemical degradation of phenol on different electrodes. Water Res. 2005, 39, 1972-1981. [CrossRef] [PubMed]

5. Ma, H.; Zhang, X.; Ma, Q.; Wang, B. Electrochemical catalytic treatment of phenol wastewater. J. Hazard. Mater. 2009, 165, 475-480. [CrossRef] [PubMed]

6. Li, M.; Feng, C.; Hu, W.; Zhang, Z.; Sugiura, N. Electrochemical degradation of phenol using electrodes of $\mathrm{Ti} / \mathrm{RuO}_{2}-\mathrm{Pt}$ and Ti/IrO${ }_{2}-\mathrm{Pt}$. J. Hazard. Mater. 2009, 162, 455-462. [CrossRef] [PubMed]

7. Jin, P.; Chang, R.; Liu, D.; Zhao, K.; Zhang, L.; Ouyang, Y. Phenol degradation in an electrochemical system with $\mathrm{TiO}_{2}$ /activated carbon fiber as electrode. J. Environ. Chem. Eng. 2014, 2, 1040-1047. [CrossRef]

8. Hammani, H.; Boumya, W.; Laghrib, F.; Farahi, A.; Lahrich, S.; Aboulkas, A.; El Mhammedi, M.A. Electro-catalytic effect of $\mathrm{Al}_{2} \mathrm{O}_{3}$ supported onto activated carbon in oxidizing phenol at graphite electrode. Mater. Today Chem. 2017, 3, 27-36. [CrossRef]

9. Awad, Y.M.; Abuzaid, N.S. Electrochemical oxidation of phenol using graphite anodes. Sep. Sci. Technol. 1999, 34, 699-708. [CrossRef]

10. Ghoreishi, S.M.; Behpour, M.; Hajisadeghian, E.; Golestaneh, M. Voltammetric determination of resorcinol on the surface of a glassy carbon electrode modified with multi-walled carbon nanotube. Arab. J. Chem. 2016, 9, S1563-S1568. [CrossRef]

11. Feng, Y.; Yang, L.; Liu, J.; Logan, B.E. Electrochemical technologies for wastewater treatment and resource reclamation. Environ. Sci. Water Res. Technol. 2016, 2, 800-831. [CrossRef]

12. Tasic, Z.; Gupta, V.K.; Antonijevic, M.M. The mechanism and kinetics of degradation of phenolics in wastewaters using electrochemical oxidation. Int. J. Electrochem. Sci. 2014, 9, 3473-3490.

13. El-Ashtoukhy, E.S.Z.; El-Taweel, Y.A.; Abdelwahab, O.; Nassef, E.M. Treatment of petrochemical wastewater containing phenolic compounds by electrocoagulation using a fixed bed electrochemical reactor. Int. J. Electrochem. Sci. 2013, 8, 1534-1550.

14. Vasudevan, S. An efficicent removal of phenol from water by peroxi-electrocoagulation processes. J. Water Proc. Eng. 2014, 2, 53-57. [CrossRef]

15. Phutdhawong, W.; Chowwanapoonpohn, S.; Buddhasukh, D. Electrocoagulation and subsequent recovery of phenolic compounds. Anal. Sci. 2000, 16, 1083-1084. [CrossRef]

16. Mohammed, A.A. Electrocoagulation of phenol for wastewater treatment. Iraqi J. Chem. Petrol. Eng. 2007, 9, $37-41$.

17. Zazouli, M.A.; Taghavi, M. Phenol removal from aqueous solutions by electrocoagulation technology using iron electrodes: Effect of some variables. J. Water Res. Prot. 2012, 4, 980-983. [CrossRef]

18. Zazouli, M.A.; Taghavi, M.; Bazrafshan, E. Influences of solution chemistry on phenol removal from aqueous environments by electrocoagulation process using aluminum electrodes. J. Health Scope 2012, 1, 66-70. [CrossRef]

19. Bazrafshan, E.; Biglari, H.; Mahvi, A.H. Phenol removal by electrocoagulation process from aqueous solutions. Fresenius Environ. Bull. 2012, 21, 364-371.

20. Uhlig, H.H.; Revie, R.W. Corrosion and Corrosion Control: An Introduction to Corrosion Science and Engineering, 3rd ed.; John Wiley \& Sons: New York, NY, USA, 1985; pp. 101-105, ISBN 0-471-07818-2.

21. Pierozynski, B.; Smoczynski, L. Electrocoagulator for Wastewater Treatment. Polish Patent PL 227874, 5 September 2017.

22. Andrade, L.S.; Laurindo, E.A.; de Oliveira, R.V.; Rocha-Filho, R.C.; Cass, Q.B. Development of a HPLC method to follow the degradation of phenol by electrochemical or photoelectrochemical treatment. J. Braz. Chem. Soc. 2006, 17, 369-373. [CrossRef]

23. Bielicka-Daszkiewicz, K.; Hadzicka, M.; Voelkel, A. Optimization of SPE/GC/HPLC analytical procedure for determination of phenol, quinones, and carboxylic acids in water samples. ISRN Chromatogr. 2012, 2012. [CrossRef]

24. Qiao, J.Q.; Yuan, N.; Tang, C.J.; Yang, J.; Zhou, J.; Lian, H.Z.; Dong, L. Determination of catalytic oxidation products of phenol by RP-HPLC. Res. Chem. Intermed. 2012, 38, 549-558. [CrossRef]

25. Yuan, C.-G. Progress of optical determination for phenolic compounds in sewage. J. Environ. Sci. 1998, 10, $76-86$.

26. Dolatto, R.G.; Messerschmidt, I.; Pereira, B.F.; Silveira, C.A.P.; Abate, G. Determination of phenol and o-cresol in soil extracts by flow injection analysis with spectrophotometric detection. J. Braz. Chem. Soc. 2012, 23, 970-976. [CrossRef] 
27. Mendham, J.; Denney, R.C.; Barnes, J.D.; Thomas, M. Vogel's Textbook of Quantitative Chemical Analysis, 6th ed.; Prentice Hall: Upper Saddle River, NJ, USA, 2000; ISBN 13. 2900582226288.

28. Abdulkadir, M.Q. Proceeding bromometric phenol assay without starch indicator. Iraqi J. Pharm. Sci. 2009, 18, 72-77.

29. Duan, X.; Zhao, Y.; Liu, W.; Chang, L. Investigation on electro-catalytic oxidation properties of carbon nanotube-Ce-modified $\mathrm{PbO}_{2}$ electrode and its application for degradation of m-nitrophenol. Arab. J. Chem. 2014. [CrossRef]

(C) 2018 by the authors. Licensee MDPI, Basel, Switzerland. This article is an open access article distributed under the terms and conditions of the Creative Commons Attribution (CC BY) license (http://creativecommons.org/licenses/by/4.0/). 